\title{
Europejska reklama i towarzysząca jej nienawiść
}

\section{W} Międzynarodowym Pakcie Praw Obywatelskich i Politycznych postanowiono, że przyrodzona godność oraz niezbywalne prawa wszystkich członków wspólnoty ludzkiej, stanowią podstawę wolności, sprawiedliwości i pokoju. Każde państwo posiada więc obowiązek popierania i przestrzegania przynależnych człowiekowi wartości i praw. W art. 17 powyższego dokumentu, zapisano, że nikt nie może być narażony na, min. bezprawną ingerencję w jego życie prywatne, rodzinne, dom lub korespondencję oraz zamachy na jego cześć i dobre imię. Podkreślono również, podobnie jak w innych dokumentach, że każdy ma prawo do wyrażania własnych poglądów. Pociąga to jednak za sobą pewną odpowiedzialność i obowiązki oraz podlega ograniczeniom, ze względu na różne cele. Zapisano, że wszelkie podżeganie do nienawiści różnego rodzaju, powinno być stanowczo zakazane przez prawo ${ }^{1}$.

Wolność słowa podlega ograniczeniom, szczególnie w przypadkach, gdy dotyczy nieuzasadnionej nienawiści wobec określonych grup społecznych z powodu ich rasy, skóry czy orientacji seksualnej. Europejski Trybunał Praw Człowieka stara się podchodzić do wolności słowa w sposób bardzo lakoniczny, biorąc pod uwagę treść wypowiedzi i jej cel.

Ograniczenie wypowiedzi musi odpowiadać społecznym potrzebom i wymaganiom. Dlatego też krajowe ustawodawstwa powinny zwracać uwagę na fakt, jaki jest cel ograniczenia i proporcje użytych środków ograniczających. Sprowadza się to do brania pod uwagę relacji pomiędzy wolnością wypowiedzi a innymi prawami przynależnymi jednostce z natury, takimi jak, przede wszystkim - godność.

Zaznaczyć należy, że nie każda wypowiedź stanowić może mowę nienawiści, ponieważ wolność wypowiedzi chroniona art. 10 Europejskiej Konwencji o Ochronie Praw Człowieka i Podstawowych Wolności, obej-

1 Międzynarodowy Pakt Praw Obywatelskich i Politycznych otwarty w Nowym Jorku dnia 19 grudnia 1966 r., Dz. U. Nr 38, poz. 167 z dnia 29 grudnia 1977 r. Załącznik. 
muje również prawo do posiadania opinii i wyrażania swoich poglądów bez ingerencji władzy. Stwierdza się, że „,zachowanie osoby, która publicznie przedstawia negatywne cechy osób należących do danego naro$\mathrm{du}$, grupy etnicznej, wyznaniowej, lecz w zachowaniu tym brak dążenia do wywołania negatywnych emocji u innych osób, wyłączy możliwość przypisania takiej osobie realizacji znamion strony przedmiotowej tego przestępstwa"2. Nie można jednak dopuścić, by wolność słowa użyta została do podburzania przemocy, szerzenia nienawiści i dyskryminacji z różnych względów. Wolność wypowiedzi ulega wszak pewnym ograniczeniom, w celu ochrony praw innych jednostek, w szczególności ich godności. Wiedzieć więc należy, gdzie przebiega granica dozwolonej krytyki a dyskusji na dany temat, tak aby obie wypowiedzi nie przeistoczyły się w nienawiść do wszystkich innych różniących się od nas.

Poza tym zauważono, że „to czy dane słowo, gest bądź zachowanie uznane zostanie za zniewagę, zależy od reguł obyczajowych występujących w danej społeczności”3. Tak więc stwierdzić można, że duże znaczenie przy klasyfikacji danego czynu w poczet mowy nienawiści będzie miała kwestia interpretacji przepisów, dokonana przez wymiar sprawiedliwości.

Zgodnie z wytycznymi Europejskiej Konwencji o Ochronie Praw Człowieka i Podstawowych Wolności oraz Konstytucji RP ograniczenia słowa i całych wypowiedzi, aby były dopuszczalne muszą spełniać następujące warunki: muszą być przewidziane w ustawie, proporcjonalne, niezbędne w demokratycznym państwie dla ochrony bezpieczeństwa, porządku, zdrowia publicznego, także dla ochrony praw i wolności innych członków społeczeństwa ${ }^{4}$ - zgodnie z wytyczną, że wolność jest zasadą, a ograniczenia wyjątkiem.

Wolność słowa to jedno z najważniejszych kryteriów wyznaczających poziom demokratycznych państw. Wolność ta nie ma i nie może mieć charakteru absolutnego. W przypadku wykorzystania jej jako mowy nienawiści ze względu na płeć, kolor skóry lub orientację seksualną wolność słowa staje się nadużyciem przekraczającym wszelkie wartości, również

2 Patrz. M. Kalitowski w: M. Bojarski, M. Filar, W. Filipkowski, O. Górniok, Komentarz do kodeksu karnego, Warszawa 2006, komentarz do art. 256 i 257.

3 Ibidem, komentarz do art. 216 Kodeksu karnego.

4 Europejska Konwencja o Ochronie Praw Człowieka i Podstawowych Wolności, Dz. U. 1993, Nr 61, poz. 284, Dz. U. 1998, Nr 147, poz. 962, art. 9, pkt 2 i art. 10 pkt 2; Konstytucja RP art. 31, Warszawa 2005, s. 9. 
etyczne. Wykładnia prawa nie obejmuje definicji mowy nienawiści. Znaleźć ją jednak można w załączniku do Rekomendacji nr 20 (97) Komitetu Ministrów Rady Europy. W świetle tego dokumentu mowa ta oznacza każdą formę wypowiedzi, która rozpowszechnia, podżega, propaguje lub usprawiedliwia nienawiść rasową, ksenofobię, antysemityzm lub inne formy nienawiści oparte na nietolerancji. Stanowisko to potwierdza również Zalecenie nr 1 Europejskiej Komisji przeciwko Rasizmowi i Nietolerancji stanowiące, że na podstawie art. 10 i 11 Europejskiej Konwencji o Ochronie Praw Człowieka i Podstawowych Wolności, wypowiedzi ustne, pisemne, audiowizualne oraz inne formy ekspresji podżegające do nienawiści, dyskryminacji oraz przemocy wobec etnicznych, rasowych i religijnych grup oraz ich członków, są prawnie klasyfikowane jako przestępstwa karne 5 .

Stwierdzenie wystąpienia mowy nienawiści w przypadku komunikatu reklamowego jest rzeczą niełatwą, pociagnięcie do odpowiedzialności karnej za taki występek wydaje się jeszcze trudniejsze. Uwagę zwrócić należy nie tylko na przedstawienia ikoniczne i slogany zawarte w reklamie, ale również na kontekst i zamiar z jakim zostały one stworzone oraz jaki wpływ wywierają na adresata, gdyż strona podmiotu jest niezbędną przesłanką przestępstwa z art. 257 k.k. ${ }^{6}$ Wypowiedź taka nabiera charakteru prawno-karnego, jeżeli czyn popełniony jest w konkretnej intencji - dolus directus coloratus, co zdarza się, w przypadku reklamy dosyć często.

Komitet Międzynarodowej Konwencji w Sprawie Likwidacji Wszelkich Form Dyskryminacji Rasowej uznał, że wolność wypowiedzi zasługuje na niższy stopień ochrony w przypadku mowy nienawiści ${ }^{7}$. Warto również zauważyć, że zarówno Europejska Konwencja o Ochronie Praw Człowieka i Podstawowych Wolności, jak i Konwencja Przeciwko Dyskryminacji Rasowej podkreślają, że zakaz mowy nienawiści jest całkowicie zgodny z przepisami odnoszącymi się do wolności wyrażania opinii i poglądów. Poza tym Europejski Trybunał Praw Człowieka orzekł, że ko-

5 Zalecenie nr 1 ECRI, CRI (96) 43, „Biuletyn Biura Informacji Rady Europy” 2005 , $\mathrm{nr} 4$.

${ }^{6}$ Znajduje to potwierdzenie w wyroku SN z dnia 5 lutego 2007 r., w którym stwierdzono, że nawoływanie do nienawiści z powodów wymienionych w art. 256 k.k., dotyczy tych wypowiedzi, które wzbudzają uczucie silnej niechęci, wrogości i złości, w stosunku do innych, podkreślając tym wyższość tych, którzy je wypowiadaja, postanowienie SN z dnia 5 lutego 2007 r., sygn. Akt IV KK 406/06, „Biuletyn Prawa Karnego", nr 5/07.

${ }^{7}$ Orzeczenie Komisji $\S 10.5$. 
nieczne jest karanie za formy wypowiedzi, które szerza, promują lub usprawiedliwiają nienawiść opartą na nietolerancji, z zastrzeżeniem zasady proporcjonalności ${ }^{8}$. Orzeczenie to, jest potwierdzeniem wcześniejszego już przekonania, że nie ma wątpliwości, co do konkretnych wypowiedzi będących mowa nienawiści, które nie znajdują ochrony przewidzianej w art. 10 Europejskiej Konwencji o Ochronie Praw Człowieka i Podstawowych Wolności.

Na szczególną uwagę zasługuje sprawa Norwood, dotycząca wywieszenia przez prawicową partię antymuzułmańskiego plakatu w Wielkiej Brytanii, który potraktować można jako reklamę prospołeczną danego ugrupowania. Sprawa ta jak dotąd jest jedyną dotyczącą przekazu reklamowego i zawartej w nim mowy nienawiści, która nagłośniona została opinii publicznej. Europejski Trybunał Praw Człowieka orzekł, że ataki tego rodzaju na grupę religijną nie podlegają ochronie gwarantowanej przez Europejską Konwencję o Ochronie Praw Człowieka i Podstawowych Wolności, a przede wszystkim precedens taki nie dotyczy tolerancji religijnej.

W przypadku mowy nienawiści i związanej z nią wolności słowa, która coraz częściej staje się elementem komunikatu reklamowego, należy rozróżnić wolność negatywną i pozytywną. Koncepcja negatywna dotyczy niezważania na godność innej jednostki oraz swobodnego wyboru zachowania i decyzji. Wolność pozytywna oznacza natomiast dokonywanie wyboru z uwzględnieniem określonych warunków, nakazuje więc racjonalne podejście do problemu? ${ }^{9}$.

Mowa nienawiści dotyczy różnych problemów i działa na nasze emocje. Prowadzi ona do utrwalenia wrogości, szerzenia stereotypów i uprzedzeń rasowych oraz zaburzyć może proces komunikacyjny. Przybierać ona może bardzo drastyczne formy, które widoczne są w przekazach pisemnych, ustnych oraz wizualnych ${ }^{10}$.

8 Gunduz v. Turcja, orzeczenie z 4 grudnia 2003 r., nr aplikacji 35071/97.

9 Patrz I. Berlin, Cztery eseje o wolności, Poznań 2000, s. 183-239.

10 Uznaje się, że mowa nienawiści dotyczy przede wszystkim zbiorowości, a nie jednostek. Oznacza to, że uderzając w danego człowieka skierowana musi być do niego jako przedstawiciela grupy, której cechy są jemu przypisywane, odbierając tym prawo bycia sobą. Ponadto mowa taka powinna być skierowana przeciwko grupie (zbiorowości), która charakteryzuje się odpowiednimi cechami, danymi jej przez naturę (kolor skóry, płeć, orientacja seksualna) lub uwarunkowaniami społecznymi (zawód, język, obywatelstwo, religia), S. Kowalski, M. Tulli, Zamiast procesu. Raport o mowie nienawiści, Warszawa 2003, s. 21-22. 
Mowa taka posiada perswazyjny mocny ton, a jej retoryka, jeśli w ogóle mówić można tu o retoryce, nastawiona jest na przekonywanie innych za wszelką cenę, nie zważając na skutki jakie może wywołać ${ }^{11}$.

Ludzie posługujący się mowa nienawiści, przekonani są o wyższości swoich poglądów i rasy. Osoby te czerpią zadowolenie z zadanego bólu i dominacji. Zmierzają oni do poniżenia innych, wywołania ataków przemocy i utrwalenia negatywnych wizerunków obrażanych osób ${ }^{12}$.

Elementem najbardziej uderzającym w reklamie jest ciągłe dokonywanie rozróżnień na białych i czarnych, homo- i heteroseksualistów, czyli mówiąc kolokwialnie próba dzielenia świata.

Kolejnym przykładem z tej grupy jest podział na Europę rozwiniętą i tą, która dopiero zaczyna się rozwijać, czyli państwa, które niedawno weszły do Unii Europejskiej. Inwazja tych elementów objawia się we wszystkich dziedzinach życia i dotyczy wyborów wszystkiego - wybrać polskie czy zachodnie. Zawarta w reklamie aluzja jest stylistycznym ozdobnikiem, który ogranicza możliwość jasnego przekazu. Emocjonalny charakter takiego komunikatu dodaje autentyczności, powodując wrażenie obcowania z prawdą, która wyrwana jest z kontekstu. Mowa tego rodzaju w reklamie, bardzo często zastępowana jest ironią, która przekazuje pseudo istotne treści, służąc podkreśleniu odmiennego stanowiska. Ironizacja pozwala w sposób sztuczny zmniejszyć powagę obraźliwego tonu komunikatu reklamowego. Bardzo często w celu odsunięcia winy na dalszy plan wykorzystuje się autorytet społeczny, który dodaje powagi głoszonym poglądom.

Przykładów nienawiści w reklamie wskazać by było można wiele. $\mathrm{Na}$ uwagę zasługuje firma Calvin Klein i Ralph Lauren. Firmy te prezentują w swoich reklamach młode osoby, eksponujące własne ciało skappo odziane. Zauważyć w tych przekazach można pośrednią aluzję do gwałtu lub zniewolenia kobiety czy dziecka. Warto również zaznaczyć, że ludzie tworzący reklamy przekonywani są przez swoich przełożonych i tzw.

11 Trafne w tym przypadku wydaje się nazwanie mowy nienawiści wypowiedzią obelżywą, obraźliwą, wywołującą określone napięcia i podburzającą do przemocy, S. Oliver, Striking a Balance: Hale Speech Freedom of Expression and Non-Discrimination, „The International and Comparative Law Quarterly”, vol. 43, No. 2 (April 1994), s. 476-478. Definicja ta, jeżeli uznać można ją za definicję dotyka bardzo ważnego elementu ludzkiego zachowania, jakim jest napięcie, które przybierać może różne formy i prowadzić do wrogich przekonań i nienawistnych zachowań.

12 Dan M. Kahan, Two liberale fallacies in the hate crimes debate, ,Law and Philosophy" 2001, s. 182. 
trenerów (mózgu), na różnego rodzaju seminariach i szkoleniach do przyjęcia postawy, że odbiorcy reklamy to ludzie upośledzeni umysłowo.

Reklamy takie nie miałyby racji bytu, gdyby swoim tematem i stylem nie trafiały do wielkiego kręgu odbiorców. Znane na całym świecie firmy, których logo kojarzy się z określoną marką produktu dysponują potężną siłą, która wyrządzić może krzywdę, jeśli zostanie spożytkowana do podsycania nienawiści. Bardzo kontrowersyjne w tym zakresie wydają się również, a może przede wszystkim reklamy włoskiego artysty - fotografa Oliviero Toscaniego. Przykładem może być cykl reklam dotyczących HIV. Plakaty przedstawiają w większości przypadków nagie osoby i wizerunki odpychających chorych, co uchodzić może za obraźliwe w stosunku do innych uczestników rynku. Oryginalność reklamy nie jest jednak wszystkim. Uwzględnić również trzeba oddziaływanie na drugiego człowieka. Istnieją przecież rzeczy, które nie wprost się pokazuje, ponieważ wywołać mogą ból. Kolejnym przykładem twórczości tego autora jest plakat ukazujący zakonnicę całującą w usta księdza oraz pole zasłane krzyżami. Kontrowersyjnym i zabarwionym nienawiścią jest również przekaz dotyczący dżinsów „Jezus” i towarzyszący mu slogan „Nie będziesz miał cudzych dżinsów przede mną". Twórca posługuje się tutaj jednym z dziesięciu przykazań jako pragmatycznym sloganem, starając się dowieść, że jest ponad wszystkim i wszystkimi, a żadna religia nie może stanąć mu na drodze do sukcesu. Słownictwo to, jakże nienawistne w stosunku do Katolików ucieleśnia język bez wyrazu i kultury. Reklama wabi nas Królestwem Niebieskim, które osiagniemy kupując towar - oczywiście, również na raty. Komunikat taki utożsamia cud z siłą nabywczą. W większości przypadków, plakaty Toscaniego, tworzone dla firmy Benetton są nikczemne i terrorystyczne, co powodować może wzmożoną nienawiść w stosunku do różnych, odmiennych grup społecznych.

Takie przekazy należy potępiać ze względu na konformizm, materializm, pseudo religijność oraz wulgarną przesadę, wyrażającą nienawiść i zazdrość odnoszącą się do wszystkiego ${ }^{13}$. Niepokojące jednak jest to, że w Polsce ludzie nie zawsze dostrzegają elementy nienawiści w reklamie. Inaczej sytuacja wygląda w krajach, gdzie system ochrony konsumenta jest lepiej rozwinięty. Przykładem może być Wielka Brytania i funkcjonująca tam Brytyjska Rada Reklamy ASA, do której wiele osób zgłasza

13 G. Elgozy, Paradoksy reklamy, Warszawa 1973, s. 25. 
skargi na przekazy naruszające ich godność i wywołujące niepożądane reakcje emocjonalne.

Sam obraz zawarty w reklamie również prowadzić może do nienawiści i uprzedmiotowienia, czego przykładem jest komunikat telefonii komórkowej Mobilking, prezentujący kobietę z przesadnym biustem, traktując ją tylko wyłącznie jako obiekt pożądania.

Slogan stosowany w reklamie, w niektórych przypadkach również potrafi być nienawistny. Stwierdzenia typu: „spójrz miłośnie na to piwo, muśnij je wargami, bo to piwo dla mężczyzn, poczujesz obecność tej, po której pozostanie rozkoszne wrażenie” lub „, pij jasne, jeśli lubisz blondynki, niektórzy wolą je na gorąco" jest ewidentnym sprowadzeniem kobiety, tylko i wyłącznie do roli obiektu seksualnego, a więc poniżeniem płci żeńskiej oraz uprzedmiotowieniem człowieka. Dyskurs reklamowy potrafi zmusić do niegodnego zachowania wobec innych. Problemy moralne w reklamie sprowadzają się tylko do zaoferowania konkretnego produktu, za pomocą inżynierii społecznej (np. manipulacja), wykorzystując do tego kłamstwa i sprośności. Moralność w reklamie przyrównać można do udomowienia psa, którego człowiek przyjął pod swój dach, a teraz próbuje go wyrzucić, dając dowód na to, że moralność w społeczeństwie zanika. To samo dotyczy reklamy, która próbuje stworzyć nam lepszy świat, a tak naprawdę chce nas tylko wykorzystać.

Prawno-karne regulacje stanowią niezbędne narzędzie w walce z mo$w q$ tego rodzaju. Jednak brak prawnej definicji mowy nienawiści, stwarza duże problemy interpretacyjne tego zjawiska. Wydaje się, że jedynym rozwiązaniem jest branie pod uwagę wszystkich reguł obyczajowych obowiązujących w danym społeczeństwie i na tej podstawie orzekanie o zaistnieniu nienawiści. Sama mowa jest zjawiskiem wykorzystywanym w nadmierny sposób przez środki społecznego przekazu i dlatego zasługuje na szczególną uwagę i czujność.

Stanowczo należy stwierdzić, że lepsze prawo i kontrola przekazów reklamowych, uchronić mogłyby niektóre jednostki i grupy społeczne przed nienawiścią ukrytą $\mathrm{w}$ sloganach i ikonach reklamowych, która wprost powinna być zakazana przez europejskie ustawodawstwa.

\section{Summary}

The paper concerns the rarely discussed subject of hate speech in advertising messages. Hate speech is primarily related to the issue of freedom of speech, which, however, is not absolute freedom. The scope of freedom of speech involves audiovisual 
statements and other forms of expression that may incite hatred, discrimination and violence against other groups. ECRI general recommendation no. 1 classifies such behaviors as criminal offences. Such statements acquire legal and penal status, provided that a certain act has been committed intentionally - dolus directus coloratus. Advertising discourse frequently forces us to treat others in an ignoble manner thus becoming a stimulus to violence. 